\title{
Peel bond strength of soft lining materials with antifungal to a denture base acrylic resin
}

\author{
Adelaida SÁNCHEZ-ALIAGA ${ }^{1}$, Cláudia Viviane Guimarães PELLISSARI², Cesar Augusto Galvão ARRAIS , \\ Milton Domingos MICHÉL ${ }^{3}$, Karin Hermana NEPPELENBROEK ${ }^{4}$ and Vanessa Migliorini URBAN ${ }^{1}$ \\ ${ }^{1}$ Department of Dentistry, State University of Ponta Grossa, Av. General Carlos Cavalcanti 4748, Uvaranas, 84030-900, Ponta Grossa, Paraná, \\ Brazil \\ ${ }^{2}$ Department of Dental Materials and Prosthodontics, Araraquara Dental School, Sao Paulo State University, Rua Humaitá 1680, Centro, 14801-903, \\ Araraquara, São Paulo, Brazil \\ ${ }^{3}$ Department of Materials Engineering, State University of Ponta Grossa, Av. General Carlos Cavalcanti 4748, Uvaranas, 84030-900, Ponta Grossa, \\ Paraná, Brazil \\ ${ }^{4}$ Department of Prosthodontics, Bauru School of Dentistry, University of Sao Paulo, Al. Octávio Pinheiro Brisola 9-75, Vila Universitária, 17012-901, \\ Bauru, São Paulo, Brazil \\ Corresponding author, Vanessa Migliorini URBAN; E-mail: vanurban@yahoo.com
}

\begin{abstract}
The effect of the addition of nystatin, miconazole, ketoconazole, chlorhexidine, and itraconazole into the soft lining materials Softone and Trusoft on their peel bond strength to a denture base acrylic resin was evaluated. Specimens of soft lining materials $(n=7)$ were made without (control) or with the incorporation of antifungals at their minimum inhibitory concentrations to the biofilm of C. albicans and bonded to the acrylic resin. Peel testing was performed after immersion in distilled water at $37^{\circ} \mathrm{C}$ for $24 \mathrm{~h}, 7$ and 14 days. Data $(\mathrm{MPa})$ were analyzed by 3-way ANOVA/Tukey-Kramer test $(\alpha=0.05)$ and the failure modes were classified. The addition of nystatin and ketoconazole did not affect the peel bond strength for up to 14 days. Most failures were predominantly cohesive within soft lining materials. With the exception of itraconazole, incorporating the antifungals into the soft lining materials did not result in values below those recommended for peel bond strength after 7 and 14 days of analysis.
\end{abstract}

Keywords: Denture stomatitis, Soft lining materials, Candida albicans, Anti-infective agents, Peel strength

\section{INTRODUCTION}

Infection of the oral cavity by Candida spp., called oral candidiasis, is considered the most common fungal infection in humans, especially in the elderly and denture wearers ${ }^{1)}$. Oral candidiasis related to the use of removable dentures is referred to as denture stomatitis and is considered the most common injury among users of these prostheses ${ }^{2}$. Although the etiology is considered multifactorial, infection by Candida spp., especially $C$. albicans, is considered the main etiological factor ${ }^{3)}$.

Treatments directed to denture stomatitis are varied and may include topical and systemic antifungal therapy, oral hygiene care, procedures for denture cleaning and disinfection, replacement of old dentures, eliminating anatomical irregularities, restoring nontraumatic occlusion, and nutritional restitution ${ }^{4}$. Additionally, in order to protect and preserve the mucosal integrity, the patient should sleep without dentures ${ }^{5}$. The choice of a treatment or a combination of them should be individually considered.

Soft lining materials have been widely used, such as dynamic impression materials, and are essential adjuncts for the treatment of oral mucosa traumatized by residual ridge resorption, damage to the inner surface of removable dentures or surgery ${ }^{6}$. This is due to the fact that these materials aid the recovery of tissues that are in contact with the denture base, ensuring patient comfort $^{7)}$. The soft lining material absorbs part of the chewing forces on the prosthesis during function, thus reducing the energy transmitted to the associated periprosthetic tissues. However, a major disadvantage or cause of failure in soft lining material is their difficult cleaning, since they are significantly softer and less resistant to brushing than conventional acrylic resins ${ }^{8)}$. Thus, soft lining materials, especially temporary ones, are easily degradable and susceptible to microbial colonization $^{9}$, which may favor the installation of pathological processes and impair the treatment of existing infections ${ }^{10)}$.

To prolong the clinical longevity of soft lining materials and reduce the possibility of biofilm accumulation, some authors have incorporated antifungal agents in such materials ${ }^{6,11,12)}$. This combination can be a therapeutic rationale in the treatment of denture stomatitis by several factors: 1) reduction of trauma caused by the inner surface of the rigid heat-cured acrylic resin of removable dentures; 2) eliminating contact of the contaminated surface with the oral tissues, consequently interrupting the cycle of re-infection; and 3) the action of antifungal agents incorporated into the material directly on the infected tissues $^{11,12)}$.

However, it has been shown that the incorporation of antifungals into soft lining materials can affect their structural properties ${ }^{7)}$ and tensile strength ${ }^{13)}$. Soft lining materials must remain bonded to the acrylic denture bases of the removable prosthesis to adequately perform 
their function ${ }^{14)}$. During clinical use, soft lining materials are subjected to conditions that initiate the peeling and may result in the infiltration of fluids in the bonding interface ${ }^{15)}$, creating a potential surface for bacterial growth and biofilm formation ${ }^{16)}$. Clinical failures when using these materials are attributed to loss of bonding to the acrylic-based resin, therefore measurements of the bond strength are very important ${ }^{17}$.

Several studies have tested the strength to detachment to evaluate the bond of soft lining materials to the denture base resin ${ }^{18-23)}$. However, so far, no study has analyzed the peel bond strength of soft lining materials after addition of antifungals at lower concentrations, defined as effective for the inhibition of Candida spp. Thus, based on these considerations, this study assessed the effect of minimal inhibitory concentrations (MIC) against the biofilm of C. albicans, previously determined for five antifungal agents (nystatin, miconazole, ketoconazole, chlorhexidine, and itraconazole) ${ }^{24)}$, added into soft lining materials (Softone and Trusoft), on the peel bond strength to a denture base acrylic resin. The null hypothesis was that drug incorporation at MICs does not affect the peel bond strength of both soft lining materials to the denture base acrylic resin after immersion in water.

\section{MATERIALS AND METHODS}

Two soft lining materials with different usages; one tissue conditioner and one temporary resilient liner, were selected for this study (Table 1). The antifungal agents evaluated in this study are presented in Table 2.

Specimens $(n=7)$ of denture base acrylic resin Lucitone 550 (Dentsply, York, PA, USA) were made with dimensions of $75 \times 10 \times 3 \mathrm{~mm}^{22,23,25)}$. For this purpose, impressions were taken from stainless steel matrices with these dimensions using laboratory silicone (Zetalabor, Zhermack, Rovigo, Veneto, Italy) between two glass plates. This set (impression/matrix) was invested in conventional metal dental flasks using type III dental stone (Herodent, Vigodent, Rio de Janeiro, RJ, Brazil). After the stone setting time, the flask was opened and the stainless steel matrix was removed. The heatcured acrylic resin was proportioned, mixed according to the manufacturer's instructions and inserted into the silicone impression. The flask was closed and kept under a load of $1.25 \mathrm{t}$ in a hydraulic press for $30 \mathrm{~min}$. After this period, the specimens were subjected to short-cycle

Table 1 Soft lining materials chosen for this study

\begin{tabular}{|c|c|c|c|c|c|c|c|c|c|}
\hline \multirow{2}{*}{ Material } & \multirow{2}{*}{$\begin{array}{l}\text { Type/Usage } \\
\text { period }\end{array}$} & \multicolumn{2}{|c|}{ Batch } & \multicolumn{2}{|c|}{ Composition } & \multirow{2}{*}{$\begin{array}{c}\text { Powder/liquid } \\
\text { ratio } \\
(\mathrm{g} / 1 \mathrm{~mL})\end{array}$} & \multirow{2}{*}{$\begin{array}{l}\text { Working } \\
\text { times } \\
(\min )\end{array}$} & \multirow{2}{*}{$\begin{array}{l}\text { Setting } \\
\text { times } \\
(\mathrm{min})\end{array}$} & \multirow{2}{*}{ Manufacturer } \\
\hline & & Powder & Liquid & Powder & Liquid & & & & \\
\hline Softone ${ }^{\mathrm{TM}}$ & 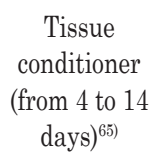 & $1002-035$ & $1108-346$ & $\begin{array}{c}\text { Polyethyl } \\
\text { methacrylate } \\
\text { (PEMA), } \\
\text { titanium dioxide }\end{array}$ & $\begin{array}{c}\text { Dibutyl phthalate } \\
\text { and butyl } \\
\text { benzoate }^{65)} \\
\text { ethyl-alcohol }\end{array}$ & 1 & 1 & $\begin{array}{l}\qquad-7 \\
\text { at room } \\
\text { temperature }\end{array}$ & $\begin{array}{l}\text { Bosworth } \\
\text { Company, } \\
\text { Skokie, IL, } \\
\text { USA }\end{array}$ \\
\hline Trusoft ${ }^{\mathrm{TM}}$ & $\begin{array}{l}\text { Resilient } \\
\text { liner } \\
\text { (up to } 6 \\
\text { months) }\end{array}$ & $1208-364$ & $1211-495$ & $\begin{array}{c}\text { PEMA, } \\
\text { titanium dioxide }\end{array}$ & $\begin{array}{l}\text { Alkyl phthalate, } \\
\text { ethyl-alcohol }\end{array}$ & 1 & 1 & $\begin{array}{l}\qquad \begin{array}{l}5-7 \\
\text { at room } \\
\text { temperature }\end{array}\end{array}$ & $\begin{array}{l}\text { Bosworth } \\
\text { Company }\end{array}$ \\
\hline
\end{tabular}

Table 2 Antifungal agents evaluated in this study and the previously determined minimum inhibitory concentrations for the biofilm of $C$. albicans

\begin{tabular}{lccl}
\hline \multicolumn{1}{c}{ Drug/Acronym } & Batch & MIC $^{24)}$ for each g of material $(\mathrm{g})$ & \multicolumn{1}{c}{ Manufacturer } \\
\hline Nystatin (Ny) & 12030665B & 0.032 & $\begin{array}{l}\text { Pharmanostra, Rio de Janeiro, RJ, } \\
\text { Brazil } \\
\text { Galena Química e Farmacêutica, }\end{array}$ \\
Miconazole (Mc) & 1207033303 & 0.256 & $\begin{array}{l}\text { Campinas, SP, Brazil } \\
\text { Campera }\end{array}$ \\
Ketoconazole (Ke) & 1211004307 & 0.128 & Galena Química e Farmacêutica \\
Chlorhexidine (Chx) & $206986-79-0$ & 0.064 & $\begin{array}{l}\text { Acros Organics, Morris Plains, NJ, } \\
\text { USA }\end{array}$ \\
Itraconazole (It) & 1209003409 & 0.256 & Galena Química e Farmacêutica \\
\hline
\end{tabular}


polymerization as recommended by the manufacturer (90 $\mathrm{min}$ at $73^{\circ} \mathrm{C}$ and then boiling water for $30 \mathrm{~min}$ ). The flasks were then bench cooled for 30 min followed by cooling under running water for $15 \mathrm{~min}$.

Afterwards, the specimens were removed from the impressions and stored in distilled water at $37^{\circ} \mathrm{C}$ for 48 $\mathrm{h}^{26)}$. After the storage period, the flat smooth surface (side in contact with the glass slide) was abraded automatically in a polishing machine using \#600 silicon carbide abrasive paper (Norton Abrasivos, São Paulo, SP, Brazil) under constant irrigation. The abraded surface was cleaned with detergent for $20 \mathrm{~s}$, washed under running water, and dried.

The specimens were then placed in a hollow stainless steel matrix with internal dimensions of $75 \times 10 \times 6$ $\mathrm{mm}$. The specimen area $\left(650 \mathrm{~mm}^{2}\right)$ that should not be bonded to the modified soft lining material was covered with a polyester strip ${ }^{23,25)}$. The quantities of antifungal powder (Table 2) were manually mixed to the powder of the soft lining materials to obtain a homogeneous mixture $^{7}$. The liquid of soft lining materials was added to the powder mixture and the material was prepared according to the manufacturer's instructions (Table 1). The soft lining material modified or not by the addition of antifungals (control group-Ct) was inserted into the hollow matrix containing the heat-cured acrylic resin specimen prepared for the reline procedure. This assembly was covered with a glass slide and kept under digital pressure during the gelation/polymerization time recommended by the manufacturer (Table 1). The excess material was removed and the relined specimens were stored in distilled water at $37^{\circ} \mathrm{C}$ for $24 \mathrm{~h}, 7$ or 14 days.

The peel bond strength test was analyzed in a universal testing machine (Autograph AG-I, Shimadzu do Brasil, São Paulo, SP, Brazil) with $50 \mathrm{~N}$ load cell (Shimadzu do Brasil) at an angle of $180^{\text {o22,23,25) }}$ and speed of $50 \mathrm{~mm} / \mathrm{s}$. The portion of modified soft lining material not attached to the resin base $(65 \mathrm{~mm})$ was folded and fixed in the upper clutch of the equipment at $20 \mathrm{~mm}$ from the bonded area of the specimen. The other non-relined portion of the heat-cured resin was pressed on the lower clutch of the equipment ${ }^{22,23,25)}$ at $20 \mathrm{~mm}$ from the bonded area of the specimen. Each specimen was subjected to tension to promote peeling of the modified soft lining material from the heat-cured acrylic resin. The results of the rupture force were transformed into peel bond strength in $\mathrm{MPa}^{22,23,27)}$.

Bond failures were observed in a stereomicroscope $(8 \times)$ and characterized as: adhesive, when peeling occurred between the modified soft lining material and the denture base acrylic resin; cohesive, when there was tearing (rupture of the soft lining material within the area bonded to the denture base) or snapping (soft lining material had stretched and then ruptured away from the bonded area) within the modified soft lining material; and mixed, when regions with two types of failure were observed on the surface of the denture base material.

Data were submitted to three-way analysis of variance followed by Tukey-Kramer test $(\alpha=0.05)$, using the software (SAS 8.0 for Windows, SAS Institute, Cary, NC, USA). Post-hoc power analysis was performed for statistical analysis of peel bond strength data using the personal statistical software (SPSS 19, SPSS, IBM Company, Armonk, NY, USA).

\section{RESULTS}

For the number of specimens used to evaluate the peel bond strength between the denture base and modified soft lining materials $(n=7)$, this study presented adequate power for all factors "Material", "Antifungal" and "Time" $(100 \%, \alpha=0.05)$. The results of threeway ANOVA showed statistical significance for all isolated factors $(p<0.0001)$ and for the interactions "Material" $\times$ "Antifungal" ( $p=0.0231)$, "Material" $\times$ "Time" and "Antifungal" $\times$ "Time" $(p<0.0001)$. The mean values and statistical significance of results are shown in Tables 3, 4 and 5 and Figs. 1 and 2 .

According to Table 3, there was no statistically significant difference $(p>0.05)$ between groups modified by the addition of $\mathrm{Ny}$, Ke and Chx compared to the control group for the Softone material. The incorporation of $\mathrm{Mc}$ resulted in statistically higher values of peel bond strength to the denture base $(p=0.0224)$ than the group without drug incorporation for the Softone material. The group modified by adding It showed the

Table 3 Means, standard deviation, and statistical significance of peel bond strength (MPa) for the interaction "Material"×“Antifungal", regardless of the immersion time

\begin{tabular}{cccccccc}
\hline \multirow{2}{*}{ Material } & \multicolumn{5}{c}{ Antifungal agents } \\
\cline { 2 - 7 } & $\mathrm{Ct}$ & $\mathrm{Ny}$ & $\mathrm{Mc}$ & $\mathrm{Ke}$ & $\mathrm{Chx}$ & $\mathrm{It}$ \\
\hline \multirow{2}{*}{ Softone } & 0.0590 & 0.0638 & 0.0699 & 0.0536 & 0.0552 & 0.0424 \\
& $(0.0111) \mathrm{BCa}$ & $(0.0065) \mathrm{ABa}$ & $(0.0090) \mathrm{Aa}$ & $(0.0072) \mathrm{Ca}$ & $(0.0078) \mathrm{BCa}$ & $(0.0074) \mathrm{Da}$ \\
Trusoft & 0.0543 & 0.0461 & 0.0596 & 0.0462 & 0.0454 & 0.0366 \\
& $(0.0059) \mathrm{ABa}$ & $(0.0055) \mathrm{BCb}$ & $(0.0099) \mathrm{Aa}$ & $(0.0074) \mathrm{BCa}$ & $(0.0076) \mathrm{Cb}$ & $(0.0056) \mathrm{Da}$ \\
\hline
\end{tabular}

Horizontally, means with identical capital letters were not significantly different $(p>0.05)$.

Vertically, means with identical small letters were not significantly different $(p>0.05)$. 
Table 4 Means, standard deviation, and statistical significance of peel bond strength (MPa) for the interaction "Material"×"Time", regardless of the antifungal addition

\begin{tabular}{cccc}
\hline & & \multicolumn{2}{c}{ Time } \\
\cline { 2 - 4 } Material & $24 \mathrm{~h}$ & 7 days & 14 days \\
\hline Softone & $0.0417(0.0068) \mathrm{Ca}$ & $0.0605(0.0093) \mathrm{Ba}$ & $0.0697(0.0085) \mathrm{Aa}$ \\
Trusoft & $0.0424(0.0047) \mathrm{Ba}$ & $0.0502(0.0087) \mathrm{Ab}$ & $0.0516(0.0075) \mathrm{Ab}$ \\
\hline
\end{tabular}

Horizontally, means with identical capital letters were not significantly different $(p>0.05)$.

Vertically, means with identical small letters were not significantly different $(p>0.05)$.

Table 5 Means, standard deviation, and statistical significance of peel bond strength (MPa) for the interaction "Antifungal" $\times$ "Time", regardless of the materials

\begin{tabular}{|c|c|c|c|c|c|c|}
\hline \multirow{2}{*}{ Time } & \multicolumn{6}{|c|}{ Antifungal agents } \\
\hline & $\mathrm{Ct}$ & $\mathrm{Ny}$ & $\mathrm{Mc}$ & $\mathrm{Ke}$ & Chx & It \\
\hline $24 \mathrm{~h}$ & $\begin{array}{c}0.0448 \\
(0.0052) \mathrm{ABb}\end{array}$ & $\begin{array}{c}0.0402 \\
(0.0058) \mathrm{ABb}\end{array}$ & $\begin{array}{c}0.0512 \\
(0.0102) \mathrm{Ab}\end{array}$ & $\begin{array}{c}0.0396 \\
(0.0035) \mathrm{Bb}\end{array}$ & $\begin{array}{c}0.0376 \\
(0.0060) \mathrm{Bb}\end{array}$ & $\begin{array}{c}0.0387 \\
(0.0040) \mathrm{Ba}\end{array}$ \\
\hline 7 days & $\begin{array}{c}0.0580 \\
(0.0118) \mathrm{Aa}\end{array}$ & $\begin{array}{c}0.0632 \\
(0.0046) \mathrm{Aa}\end{array}$ & $\begin{array}{c}0.0634 \\
(0.0069) \mathrm{Ab}\end{array}$ & $\begin{array}{c}0.0518 \\
(0.0118) \mathrm{Aa}\end{array}$ & $\begin{array}{c}0.0582 \\
(0.0084) \mathrm{Aa}\end{array}$ & $\begin{array}{c}0.0375 \\
(0.0108) \mathrm{Ba}\end{array}$ \\
\hline 14 days & $\begin{array}{c}0.0671 \\
(0.0086) \mathrm{ABa}\end{array}$ & $\begin{array}{c}0.0614 \\
(0.0077) \mathrm{Ba}\end{array}$ & $\begin{array}{c}0.0797 \\
(0.0114) \mathrm{Aa}\end{array}$ & $\begin{array}{c}0.0584 \\
(0.0068) \mathrm{Ba}\end{array}$ & $\begin{array}{c}0.0552 \\
(0.0087) \mathrm{Ba}\end{array}$ & $\begin{array}{c}0.0423 \\
(0.0048) \mathrm{Ca}\end{array}$ \\
\hline
\end{tabular}

Horizontally, means with identical capital letters were not significantly different $(p>0.05)$.

Vertically, means with identical small letters were not significantly different $(p>0.05)$.

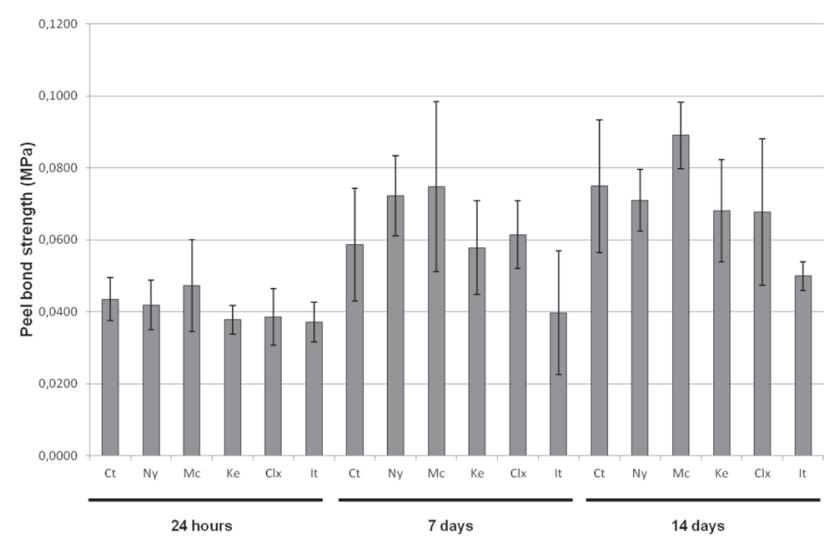

Fig. 1 Means and standard deviation of peel bond strength (MPa) of Softone.

lowest values $(p<0.0001)$ of peel bond strength for the Softone material. There was no statistically significant difference $(p>0.05)$ between the control group and those modified by the incorporation of $\mathrm{Ny}, \mathrm{Mc}$ and $\mathrm{Ke}$ for the Trusoft material. Both the addition of Chx $(p=0.0265)$ and It $(p<0.0001)$ resulted in statistically lower peel bond strength values than the control group, and incorporating It also resulted in the lowest values of peel bond strength for the Trusoft material.

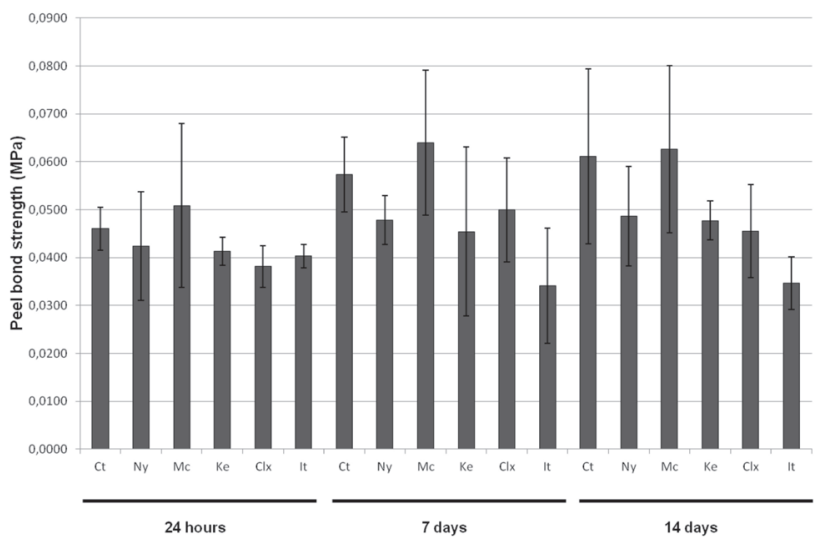

Fig. 2 Means and standard deviation of peel bond strength (MPa) of Trusoft.

Comparing the Softone and Trusoft materials, there was no statistically significant difference $(p>0.05)$ in the peel bond strength to the denture base, except for the groups modified by $\mathrm{Ny}(p<0.0001)$ or $\mathrm{Chx}(p=0.0295)$, in which the Softone tissue conditioner showed significantly higher values (Table 3).

Table 4 shows that the values of peel bond strength significantly increased $(p<0.0001)$ over time for both materials evaluated, and in the case of the 


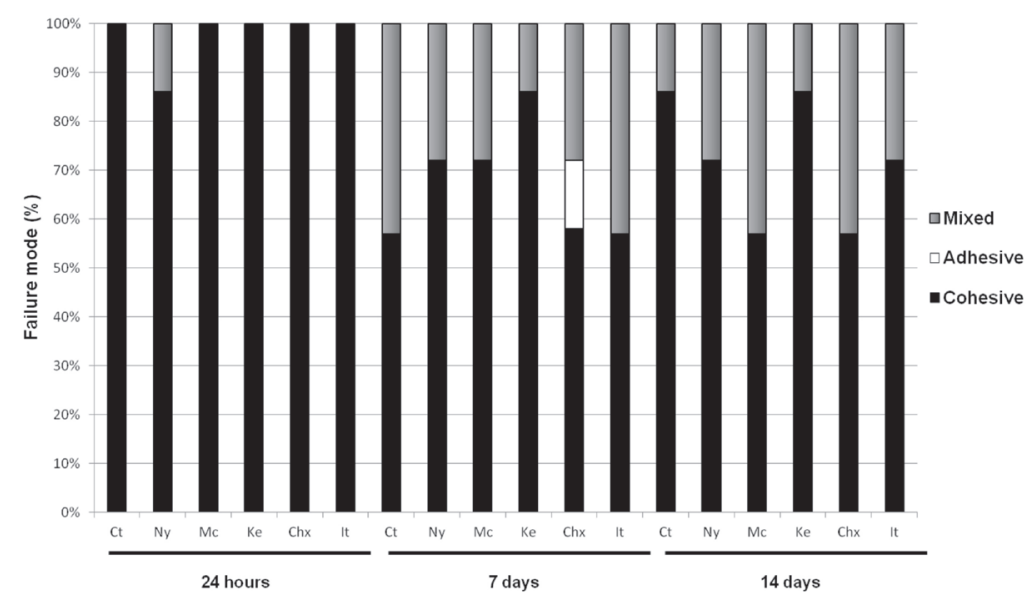

Fig. 3 Failure type (\%) for Softone specimens in the peel strength test.

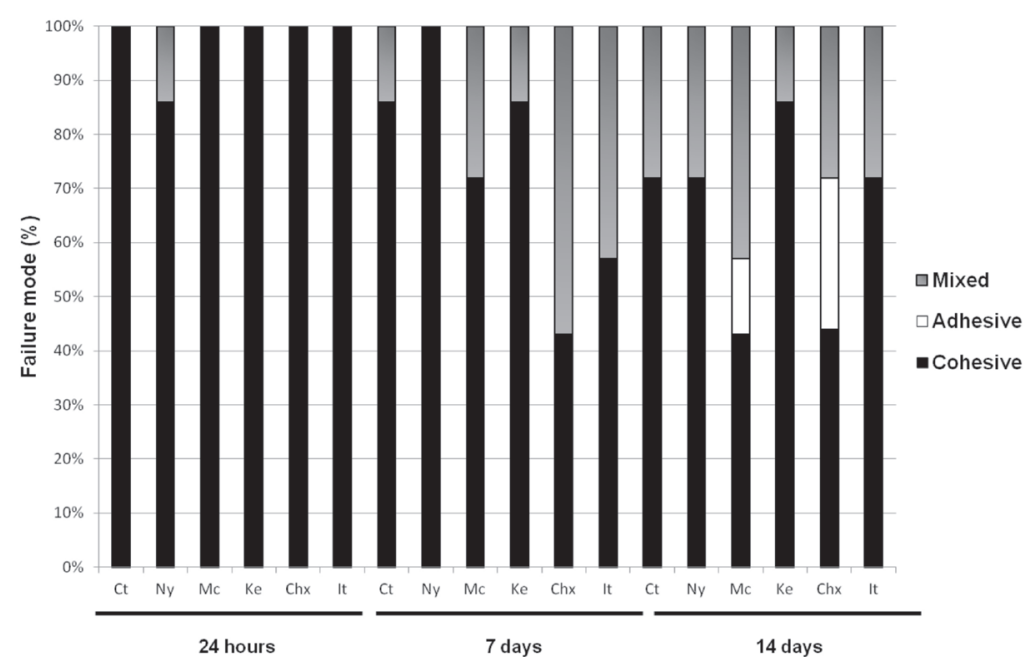

Fig. 4 Failure type (\%) for Trusoft specimens in the peel strength test.

Trusoft resilient liner there was significant increase $(p=0.0007)$ up to 7 days, and thereafter the values remained unchanged $(p>0.05)$. The increased values were noticeably more significant for the Softone tissue conditioner, once within $24 \mathrm{~h}$ the materials showed no statistically significant results of peel bond from each other $(p>0.05)$, and with increasing time significantly higher values were detected $(p<0.0001)$ for the tissue conditioner.

As observed in Table 5, there was no statistically significant difference between groups modified by the addition of drugs and the control group $(p>0.05)$ within 24 h. At the 7 and 14 day periods, only the group containing It showed statistically different values, which were lower than those of the control group $(p<0.0001)$. There was an increasing trend in peel bond strength with time at least 7 days after immersion in distilled water for the specimens of groups modified or not by the addition of drugs $(p<0.05)$, except for the group containing It, which did not present change in peel bond strength values during the evaluation period $(p>0.05)$.

Figures 3 and 4 show the failure patterns observed for the specimens after the peel bond strength test for the Softone and Trusoft materials, respectively. The majority of failures were cohesive within each soft lining material. Adhesive and mixed failures were observed for both materials mainly after immersion in distilled water for 7 and 14 days.

\section{DISCUSSION}

The incorporation of antifungal agents into the soft lining materials has the potential to become a logical treatment for denture stomatitis. This therapy can reduce the trauma caused by old dentures, conditioning periprosthetic tissues in combination with antifungal treatment; thereby, important etiological factors in the development of infection by Candida spp. would be 
eliminated simultaneously. Furthermore, this method favors a relined denture that can be kept clean by the patient more easily ${ }^{12,23)}$.

In the present study, we selected five antifungal agents based on an initial research that determined the MICs of these drugs, which are commonly used for denture stomatitis treatment, when they are incorporated into soft lining materials ${ }^{24)}$. The polyene fungicidal agent nystatin has water insoluble molecules and presents the widest spectrum of activity among the available antifungals. The nystatin polyenes bind to ergosterol, a major component of the fungal cell membrane. When present in sufficient concentrations, it forms pores in the membrane that lead to potassium leakage, acidification, and fungus death ${ }^{28,29)}$, and is used for topical treatment. In comparison to other antifungals, this drug has some advantages, such as high effectiveness in inhibiting Candida spp. ${ }^{30,31)}$, rare detection of resistant fungal strains, and accessible cost $^{31)}$. The azole antifungals such as miconazole, ketoconazole, and itraconazole, interfere primarily with fungal synthesis of ergosterol as well as certain enzymes. They work mainly by inhibiting the enzyme cytochrome P450 14-alpha-demethylase, which participates in the sterol biosynthesis pathway that leads from lanosterol to ergosterol, thus resulting in oxidative damages ${ }^{28}$. Azoles are relatively water insoluble and considered fundamentally fungistatic, although they may present fungicidal action in some in vivo situations. In addition, some azoles agents as miconazole have some antiparasitic and antibacterial properties ${ }^{29}$. The molecular structure of chlorhexidine, the best bisguanidine synthesized as antimicrobial, is composed of a hexamethylene bridge with 4-chlorophenyl terminal groups, giving cationic characteristics to this compound. Chlorhexidine is largely used as antiseptics and disinfectants for removable dentures for prevention and treatment of oral infections $s^{3,32)}$ because of its substantivity ${ }^{33,34)}$ and wide spectrum of action upon bacterial and fungal biofilms ${ }^{35-37)}$. Furthermore, compared with conventional antimycotic drugs, the emergence of chlorhexidine-resistant strains has not been reported clinically ${ }^{37,38)}$.

Despite the advantages of drug incorporation in soft lining materials, prior to the use of this alternative therapeutic modality in patients with denture stomatitis, a matrix modified by the incorporation of antifungal agents should be obtained. In this regard, modified matrix should be effective in leaching and inhibiting the growth of those microorganisms related to the pathology development and should not present deleterious effects on the structural, physical, and mechanical properties of soft lining materials. In order to evaluate a material as a drug delivery system for the treatment of denture stomatitis, two temporary acrylic-based soft linings (one tissue conditioner and one resilient liner) were chosen because they present a matrix that facilitates the drug release. Physical properties such as water sorption and solubility are important attributes to enhance drug delivery from the material ${ }^{39)}$ so systems presenting higher sorption and solubility would be potential drug carriers ${ }^{40,41)}$. Drug elution may also be enhanced by the material porosity ${ }^{38)}$ and also due to the nonreticulated amorphous gel structure in the acrylic-based soft linings ${ }^{42,43)}$. According to some studies, soft lining materials made of acrylics showed the highest sorption and solubility in comparison to those made of silicone or polyphosphazine ${ }^{44-46}$. This is due to the hydrophilic character of the acrylic material in comparison with the other materials such as silicone rubber, polyurethane, and polyphosphazine, which are hydrophobic and have a large amount of cross-linking agent in their composition $^{44)}$. As a consequence, this feature reduces the formation of micropores through which water can enter the material ${ }^{45}$. The presence of plasticizers in the acrylic soft lining increases chain stretching, making drug diffusion easier ${ }^{44}$. It has also been demonstrated that acrylic-based linings show more leachability than silicone-based materials ${ }^{47)}$, and because of that materials presenting higher release values of antimicrobials also presented larger inhibition zones of $C$. albicans ${ }^{48)}$. In addition, product presentation as powder and liquid in Softone and Trusoft acrylic lining materials makes drug incorporation facilitated.

During clinical use, including procedures for prosthesis cleaning and disinfection, soft lining materials are subjected to conditions that initiate their tear/ peeling, thus bond strength analysis of these materials are important to predict their clinical performance ${ }^{17)}$. The most commonly used methods to assess this phenomenon are the shear, tensile, and peel bond strength tests ${ }^{16,49)}$. There is some discrepancy among results obtained from these methods, partly due to the complex relationship between the direction of force application during testing, the stress generated at the interface, and the mechanical properties of the soft lining material ${ }^{50)}$.

The peel bond strength test has been reported as the most significant method to predict the material bonding in clinical conditions, since the bond loss usually starts at the exposed side of the lining material through an apparent detachment process ${ }^{22,25)}$. It is considered that this test simulates the horizontal component of chewing forces causing lateral displacement of the prosthesis edges $^{19)}$, particularly in the distolingual border of the mandibular prosthesis in the mylohyoid eminence and in the distobuccal border of the prosthesis in the maxillary tuberosity region ${ }^{51}$. Furthermore, Tanimoto et $a l .{ }^{50)}$ reported the concepts of simplicity and geometry of the peel bond strength test, and Waters and Jagger ${ }^{17)}$ noted that, during preparation of specimens for this test, the lining procedure is more accurately simulated with balanced distribution of forces on the bonding area.

Loss of adhesion to the heat-cured denture base and change in the viscoelastic properties of soft lining materials are common changes during clinical use $\mathrm{e}^{25)}$. With lining detachment, the affected area becomes non-hygienic and non-functional ${ }^{52)}$. Therefore, these materials should provide satisfactory adhesion to the denture base acrylic resin to prevent potential failures at the bonding interface ${ }^{49}$. Based on the importance of 
the peel bond strength for soft lining materials, this investigation examined whether the incorporation of antifungal drugs in the obtained MIC would interfere with this property during the recommended period of denture stomatitis treatment (14 days).

The null hypothesis stating that antifungal incorporation does not affect peel bond strength of both soft lining materials to the acrylic resin was partially accepted because no significant difference was observed between experimental and control groups only when nystatin, ketoconazole, and chlorhexidine were added to Softone. On the other hand, the addition of miconazole resulted in statistically significant increase in the peel bond strength values and the addition of itraconazole reduced these values compared to the group without drug incorporation. These findings may be attributed mainly to the amount of drug incorporated into this material. The MICs used for the drugs nystatin, chlorhexidine, and ketoconazole varied between 0.032 and $0.128 \mathrm{~g}$, which are much lower than that determined for itraconazole and miconazole $(0.256 \mathrm{~g})^{24)}$.

The increased bonding values could be considered a positive aspect for the lining, preventing bacterial growth at the interface with the resin base, allowing better prosthesis cleaning and thus contributing to the patient comfort and health ${ }^{53)}$; however, this apparent increase may be an indication that the material became more rigid and probably less viscoelastic ${ }^{54)}$, reducing its impact absorption properties ${ }^{19,55)}$. The results obtained for miconazole can be attributed to its lower molecular weight and smaller particle size compared to the other antifungals ${ }^{7}$, allowing the drug to present higher diffusivity inside the matrix, leading to a higher solvation level ${ }^{56)}$.

The inferior results obtained for itraconazole, regardless of the larger amount added, can also be associated with drug processing, which is commercially available in pellets form. Even when milled and processed into an ultrafine filter, it is likely that the final powder of itraconazole still presented remaining pellets. The soft lining material absorbs water when immersed in an aqueous solution, which will affect the dimensional stability of the prosthesis ${ }^{57}$. Both the lining material and the polymers contained in the pellet absorbed water during the experiment, since a noticeably increased volume of specimens modified by itraconazole was observed, which may have affected the bond strength of Softone to the denture base. Moreover, the molecular weight of itraconazole $(705.64 \mathrm{~g} / \mathrm{mol})$ is much higher than that of miconazole $(416.12 \mathrm{~g} / \mathrm{mol})$. It has been reported an increase in drug molecule diffusion through the polymerized matrix due to its low molecular weight ${ }^{58}$. Therefore, the lower diffusivity of itraconazole into the polymeric matrix may have reduced the peel bond strength of Softone.

For the Trusoft resilient liner, the addition of miconazole did not affect the peel bond strength values in comparison to the values observed in the control group. The addition of chlorhexidine reduced the values, and the results for itraconazole also showed the same behavior observed for Softone. The same assumptions used for Softone may explain the lowest peel bond strength observed in Trusoft with itraconazole. Decreased values after chlorhexidine addition may be related to the bigger particle size ${ }^{7}$, resulting in fragility of the matrix and porosity of the modified material after its incorporation ${ }^{58}$. The porosity of the Trusoft modified by chlorhexidine is also favored by the higher solubility of its molecules in water $(0.019 \mathrm{~g} / \mathrm{mL})$.

An increase in peel bond strength values for both materials was noted throughout the immersion period. These results are probably due to the release of plasticizer contained in the materials' composition. The leaching of plasticizers causes hardening ${ }^{59}$, loss of viscoelasticity ${ }^{60)}$ and decreased elongation percentage ${ }^{61)}$, resulting in increased bond strength of the acrylic-based soft lining materials ${ }^{62)}$ with longer immersion time in aqueous solutions. The increase was more significant for Softone tissue conditioner and, at 7 and 14 days, this material showed higher values than Trusoft resilient liner. According to the literature ${ }^{63)}$, it is expected that Softone presents a greater amount of plasticizer as tissue conditioner than Trusoft does as a temporary resilient liner. Garcia et al. ${ }^{64)}$ also observed higher bond strength values for Coe Soft, which has higher amount of plasticizer when compared to Dentusoft, and both soft lining materials are similar to those evaluated in the present study. In addition, it has been reported that Softone liquid has the plasticizers dibutyl phthalate and butyl benzoate ${ }^{65}$, while Trusoft liquid has only an alkyl phthalate ${ }^{66}$. Dibutyl phthalate molecular weight $(194.19 \mathrm{~g} / \mathrm{mol})$ is lower than alkyl phthalate molecular weight $(334.44 \mathrm{~g} / \mathrm{mol})$. Moreover, probably ethanol concentration of Softone ( $8.3 \%$ in volume) is higher than that of Trusoft ${ }^{65)}$. Therefore, the reduction in the concentration of the low-molecular weight plasticizer and ethylic alcohol found in Softone is faster ${ }^{56,67)}$ than that of Trusoft.

The addition of plasticizers in the composition of soft lining materials aims to decrease the glass transition temperature of the material to a level below the intraoral temperature, and thus the modulus of elasticity of the material is reduced to a satisfactory level ${ }^{68}$. It has been suggested that the initial softness of temporary linings is due to the large amount of plasticizers ${ }^{59}$. This higher initial amount of plasticizers may be a likely explanation for the lack of difference in peel bond strength between the soft lining materials after $24 \mathrm{~h}$ of immersion in distilled water.

In the 24-h period, no difference was observed between groups modified by the drugs and the control group. After 7 and 14 days of immersion in water, only the group with itraconazole presented different and significantly lower values than the control group. This is due to the higher water absorption in specimens containing itraconazole, as previously mentioned. There was a trend in increasing the peel bond strength overtime for most groups, except for the group modified by itraconazole, which remained unchanged.

It has been reported that the bond strength results 
are highly dependent on the methodology ${ }^{21)}$ and this may explain the differences found among the studies ${ }^{55}$. Thus, the results of this study cannot be directly compared to previous studies ${ }^{18,20-22,25,27)}$ due to variations in processing techniques, dimensions, surface polishing, as well as specimen storage, crosshead speed, and brands of denture base resins and soft lining materials. Craig and Gibbons ${ }^{18)}$ and Kawano et al. ${ }^{16)}$ reported that, for clinical use, the soft lining materials must provide bond strength to the denture base resin higher than 0.45 $\mathrm{MPa}$. In general, the peel bond strength values are lower than $1 / 10$ of those obtained in the tensile bond strength test ${ }^{69)}$. Based on this parameter, it can be seen that both materials modified by the incorporation of itraconazole and all groups modified or not by any drug addition within $24 \mathrm{~h}$, exception for miconazole, showed bond strength below the recommended values if the peel bond strength was equivalent to the tensile bond strength ${ }^{69}$. All other groups showed satisfactory results.

This study showed that most failures were cohesive for both soft lining materials, whether modified or not by the addition of drugs (78.6\%). A study by Garcia et $a l .^{64)}$ also found a large amount of cohesive failures after the tensile bond strength test assessing temporary soft lining materials as those evaluated in the present study (Coe Soft: $76.0 \%$ and Dentusoft: $82.3 \%$ ). The authors explained the results by the micromechanical bond and chemical adhesion between the linings and the denture base, being respectively attributed to the surface preparation of the denture base acrylic resin through finishing with silicon carbide sandpaper and to similar substrate composition ${ }^{18,20}$. Since most failures were cohesive, the precise value of the peel bond strength could not be obtained. Cohesive failures provided information related to the material itself, rather than an adequate measurement of bond strength ${ }^{21}$. Emmer et al..$^{54)}$ suggested using the expression "strength failure" rather than "bond failure" when cohesive failures occur. Thus, the values provided by the peel bond strength test should be carefully interpreted because in most cases the specimens failed cohesively or exhibited mixed failures (Softone: $20.6 \%$ and Trusoft: $19.0 \%$ ).

In the pilot tests, some modifications were made in the methodology such as reduction in the bond area and surface roughness of the denture base acrylic resin, as well as increasing the crosshead speed, to evaluate the bond and not the cohesive strength of the material ${ }^{23}$. AlAthel and Jagger ${ }^{21)}$ observed a decrease in the tensile bond strength values and a tendency to increase the number of adhesive failures when the specimens were tested at higher speeds. According to the authors, this is due to the viscoelastic behavior of the material. At higher speed, the material performs as if it was more rigid and supports more load before failure, and low values are likely to be caused by stress concentration at the bonding interface.

Cohesive failures are indicative of low tear strength. This issue had also been noted in other studies using the peel bond strength test ${ }^{17,20)}$. If the forces applied during this test are more clinically relevant, the evaluated materials will tear or snap in forces well below those required to cause bond failure. This implies that the materials will undergo tearing rather than detachment at the denture base ${ }^{17}$.

The fact that water immersion has increased the number of mixed failures and led to adhesive failure (Softone: $0.8 \%$ and Trusoft: $2.4 \%$ ) suggests that bonding between denture base and the soft lining materials is gradually weakened ${ }^{50}$. Besides, the soft lining materials may have been hardened due to plasticizer release into water. According to McCabe et al. ${ }^{25)}$, stress concentration during the peeling test is higher in hard materials, and the softer materials should be capable of forming a more effective bond.

Laboratory tests do not necessarily represent the load to which linings are clinically subjected, since only one type of force is applied during its accomplishment. Additionally, the complex phenomenon of bonding and the fact that specimens did not simulate the prosthesis configuration impairs interpretation of the significance of laboratory peel bond strength values ${ }^{21}$. However, these tests are useful for comparisons between materials modified or not by the addition of drugs. It should be noted that the decision of using a novel treatment strategy should not be based on the observation of materials performance only from the results of one test, and a final assessment should be determined from in vivo clinical studies.

\section{CONCLUSIONS}

Based on the methodology and considering the limitations of this in vitro study, it was possible to conclude that:

1. Nystatin and ketoconazole could be added to the evaluated temporary soft lining materials in their MIC of C. albicans biofilms without interfering with the peel bond strength to the denture base for up to 14 days, which is the recommended period for the treatment of denture stomatitis.

2. The addition of antifungals, with the exception of itraconazole, into the soft lining materials did not result in values below those recommended for peel bond strength after 7 and 14 days of analysis.

\section{ACKNOWLEDGMENTS}

This study was supported by FAPESP (grant-10/07932-8).

\section{REFERENCES}

1) Akpan A, Morgan R. Oral candidiasis. Postgrad Med J 2002; 78: 455-459.

2) Coelho CM, Sousa YT, Dare AM. Denture-related oral mucosal lesions in a Brazilian school of dentistry. J Oral Rehabil 2004; 31: 135-139.

3) Banting DW, Hill SA. Microwave disinfection of dentures for the treatment of oral candidiasis. Spec Care Dentist 2001; 21: 4-8.

4) Neppelenbroek KH, Pavarina AC, Palomari Spolidorio DM, Sgavioli Massucato EM, Spolidorio LC, Vergani CE. Effectiveness of microwave disinfection of complete dentures 
on the treatment of Candida-related denture stomatitis. J Oral Rehabil 2008; 35: 836-846.

5) Carter GM, Kerr MA, Shepherd MG. The rational management of oral candidosis associated with dentures. N Z Dent J 1986; 82: 81-84.

6) Nikawa H, Yamamoto T, Hamada T, Rahardjo MB, Murata H, Nakanoda S. Antifungal effect of zeolite-incorporated tissue conditioner against Candida albicans growth and/or acid production. J Oral Rehabil 1997; 24: 350-357.

7) Urban VM, Seo RS, Giannini M, Arrais CA. Superficial distribution and identification of antifungal/antimicrobial agents on a modified tissue conditioner by SEM-EDS microanalysis: a preliminary study. J Prosthodont 2009; 18: 603-610.

8) Makila E, Honka O. Clinical study of a heat-cured silicone soft lining material. J Oral Rehabil 1979; 6: 199-204.

9) Makila E, Hopsu-Havu VK. Mycotic growth and soft denture lining materials. Acta Odontol Scand 1977; 35: 197-205.

10) Nikawa $H$, Iwanaga $H$, Kameda $M$, Hamada T. In vitro evaluation of Candida albicans adherence to soft denturelining materials. J Prosthet Dent 1992; 68: 804-808.

11) Douglas WH, Walker DM. Nystatin in denture liners -an alternative treatment of denture stomatitis. Br Dent J 1973; 135: 55-59.

12) Schneid TR. An in vitro analysis of a sustained release system for the treatment of denture stomatitis. Spec Care Dentist 1992; 12: 245-250.

13) Urban VM, de Souza RF, Arrais CA, Borsato KT, Vaz LG. Effect of the association of nystatin with a tissue conditioner on its ultimate tensile strength. J Prosthodont 2006; 15: 295299.

14) Braden M, Wright PS, Parker S. Soft lining materials - a review. Eur J Prosthodont Restor Dent 1995; 3: 163-174.

15) Sarac D, Sarac YS, Basoglu T, Yapici O, Yuzbasioglu E. The evaluation of microleakage and bond strength of a silicone-based resilient liner following denture base surface pretreatment. J Prosthet Dent 2006; 95: 143-151.

16) Kawano F, Dootz ER, Koran A, 3rd Craig RG. Comparison of bond strength of six soft denture liners to denture base resin. J Prosthet Dent 1992; 68: 368-371.

17) Waters MG, Jagger RG. Mechanical properties of an experimental denture soft lining material. J Dent 1999; 27: 197-202.

18) Craig RG, Gibbons P. Properties of resilient denture liners. J Am Dent Assoc 1961; 63: 382-390.

19) Amin WM, Fletcher AM, Ritchie GM. The nature of the interface between polymethyl methacrylate denture base materials and soft lining materials. J Dent 1981; 9: 336-346.

20) Sinobad D, Murphy WM, Huggett R, Brooks S. Bond strength and rupture properties of some soft denture liners. J Oral Rehabil 1992; 19: 151-160.

21) al-Athel MS, Jagger RG. Effect of test method on the bond strength of a silicone resilient denture lining material. J Prosthet Dent 1996; 76: 535-540.

22) Machado AL, Breeding LC, Puckett AD. Effect of microwave disinfection on the hardness and adhesion of two resilient liners. J Prosthet Dent 2005; 94: 183-189.

23) Alcantara CS, MacedoAF, GurgelBC, Jorge JH, Neppelenbroek $\mathrm{KH}$, Urban VM. Peel bond strength of resilient liner modified by the addition of antimicrobial agents to denture base acrylic resin. J Appl Oral Sci 2012; 20: 607-612.

24) Bueno M, Urban V, Barberio G, da Silva W, Porto V, Pinto L, Neppelenbroek K. Effect of antimicrobial agents incorporated into resilient denture relines on the Candida albicans biofilm. Oral Dis 2015; 21: 57-65.

25) McCabe JF, Carrick TE, Kamohara H. Adhesive bond strength and compliance for denture soft lining materials. Biomaterials 2002; 23: 1347-1352.

26) ISO. International Organization for Standardization:
Specification 1567: denture base polymers. 2nd ed. Switzerland: ISO; 1998.

27) Sertgoz A, Kulak Y, Gedik H, Taskonak B. The effect of thermocycling on peel strength of six soft lining materials. J Oral Rehabil 2002; 29: 583-587.

28) Andriole VT. Current and future antifungal therapy: new targets for antifungal therapy. Int J Antimicrob Agents 2000; 16: 317-321.

29) Rogers TR. Antifungal drug resistance: does it matter? Int $J$ Infect Dis 2002; 6: S47-53.

30) Douglas WH, Clarke DA. Physical and mechanical properties of nystatin-containing denture liners. J Prosthet Dent 1975; 34: 428-434.

31) Geerts GA, Stuhlinger ME, Basson NJ. Effect of an antifungal denture liner on the saliva yeast count in patients with denture stomatitis: a pilot study. J Oral Rehabil 2008; 35: 664-669.

32) Banting DW, Greenhorn PA, McMinn JG. Effectiveness of a topical antifungal regimen for the treatment of oral candidiasis in older, chronically ill, institutionalized, adults. J Can Dent Assoc 1995; 61: 199-200, 203-195.

33) Hennessey TS. Some antibacterial properties of chlorhexidine. J Periodontal Res Suppl 1973; 12: 61-67.

34) Redding S, Bhatt B, Rawls HR, Siegel G, Scott K, Lopez-Ribot J. Inhibition of Candida albicans biofilm formation on denture material. Oral Surg Oral Med Oral Pathol Oral Radiol Endod 2009; 107: 669-672.

35) Jenkins S, Addy M, Wade W. The mechanism of action of chlorhexidine. A study of plaque growth on enamel inserts in vivo. J Clin Periodontol 1988; 15: 415-424.

36) Gomes BP, Vianna ME, Matsumoto CU, Rossi Vde P, Zaia AA, Ferraz CC, Souza Filho FJ. Disinfection of gutta-percha cones with chlorhexidine and sodium hypochlorite. Oral Surg Oral Med Oral Pathol Oral Radiol Endod 2005; 100: 512517.

37) Salim N, Moore C, Silikas N, Satterthwaite JD, Rautemaa R. Fungicidal amounts of antifungals are released from impregnated denture lining material for up to 28 days. J Dent 2012; 40: 506-512.

38) Ryalat S, Darwish R, Amin W. New form of administering chlorhexidine for treatment of denture-induced stomatitis. Ther Clin Risk Manag 2011; 7: 219-225.

39) Riggs PD, Braden M, Patel M. Chlorhexidine release from room temperature polymerising methacrylate systems. Biomaterials 2000; 21: 345-351.

40) Patel MP, Cruchley AT, Coleman DC, Swai H, Braden M, Williams DM. A polymeric system for the intra-oral delivery of an anti-fungal agent. Biomaterials 2001; 22: 2319-2324.

41) Patel MP, Braden M. Heterocyclic methacrylates for clinical applications. III. Water absorption characteristics. Biomaterials 1991; 12: 653-657.

42) Jones DW, Hall GC, Sutow EJ, Langman MF, Robertson KN. Chemical and molecular weight analyses of prosthodontic soft polymers. J Dent Res 1991; 70: 874-879.

43) Parker S, Braden M. Formulation of tissue conditioners. Biomaterials 1990; 11: 579-584.

44) Mancuso DN, Goiato MC, Zuccolotti BC, Moreno A, dos Santos DM, Pesqueira AA. Effect of thermocycling on hardness, absorption, solubility and colour change of soft liners. Gerodontology 2012; 29: e215-219.

45) El-Hadary A, Drummond JL. Comparative study of water sorption, solubility, and tensile bond strength of two soft lining materials. J Prosthet Dent 2000; 83: 356-361.

46) Kawano F, Dootz ER, Koran A, 3rd Craig RG. Sorption and solubility of 12 soft denture liners. J Prosthet Dent 1994; 72: 393-398.

47) Brozek R, Rogalewicz R, Koczorowski R, Voelkel A. The influence of denture cleansers on the release of organic compounds from soft lining materials. J Environ Monit 2008; 
10: $770-774$.

48) Bertolini MM, Portela MB, Curvelo JA, Soares RM, Lourenco EJ, Telles DM. Resins-based denture soft lining materials modified by chlorhexidine salt incorporation: an in vitro analysis of antifungal activity, drug release and hardness. Dent Mater 2014; 30: 793-798.

49) Pinto JR, Mesquita MF, Henriques GE, de Arruda Nobilo MA. Effect of thermocycling on bond strength and elasticity of 4 long-term soft denture liners. J Prosthet Dent 2002; 88: 516-521.

50) Tanimoto Y, Saeki H, Kimoto S, Nishiwaki T, Nishiyama N. Evaluation of adhesive properties of three resilient denture liners by the modified peel test method. Acta Biomater 2009; 5: 764-769.

51) Wright PS. The success and failure of denture soft-lining materials in clinical use. J Dent 1984; 12: 319-327.

52) Wright PS. A three year longitudinal study of denture soft lining materials in clinical use. Clin Mater 1986; 1: 281-291.

53) Botega DM, Sanchez JL, Mesquita MF, Henriques GE, Consani RL. Effects of thermocycling on the tensile bond strength of three permanent soft denture liners. J Prosthodont 2008; 17: 550-554.

54) Emmer TJ Jr, Emmer TJ Sr, Vaidynathan J, Vaidynathan TK. Bond strength of permanent soft denture liners bonded to the denture base. J Prosthet Dent 1995; 74: 595-601.

55) Al-Athel M, Jagger R, Jagger D. Effect of ageing on the bond strength of a permanent denture soft lining material. J Oral Rehabil 2002; 29: 992-996.

56) Jones DW, Sutow EJ, Hall GC, Tobin WM, Graham BS. Dental soft polymers: plasticizer composite and leachability. Dent Mater 1988; 4: 1-7.

57) Kulak-Ozkan Y, Sertgoz A, Gedik H. Effect of thermocycling on tensile bond strength of six silicone-based, resilient denture liners. J Prosthet Dent 2003; 89: 303-310.

58) Brook IM, van Noort R. Drug release from acrylic polymers via channels and cracks: in vitro studies with hydrocortisone. Biomaterials 1985; 6: 281-285.

59) Murata H, Kawamura M, Hamada T, Saleh S, Kresnoadi U,
Toki K. Dimensional stability and weight changes of tissue conditioners. J Oral Rehabil 2001; 28: 918-923.

60) Jepson NJ, McCabe JF, Storer R. Age changes in the viscoelasticity of a temporary soft lining material. J Dent 1993; 21: 244-247.

61) Qudah S, Huggett R, Harrison A. The effect of thermocycling on the hardness of soft lining materials. Quintessence Int 1991; 22: 575-580.

62) Dootz ER, Koran A, Craig RG. Physical property comparison of 11 soft denture lining materials as a function of accelerated aging. J Prosthet Dent 1993; 69: 114-119.

63) Singh K, Chand P, Singh BP, Patel CB. Study of the effect of surface treatment on the long term effectiveness of tissue conditioner. J Oral Sci 2010; 52: 261-265.

64) Garcia RM, Leon BT, Oliveira VB, Del Bel Cury AA. Effect of a denture cleanser on weight, surface roughness, and tensile bond strength of two resilient denture liners. J Prosthet Dent 2003; 89: 489-494.

65) Hong G, Li Y, Maeda T, Mizumachi W, Sadamori S, Hamada $\mathrm{T}$, Murata $\mathrm{H}$. Influence of storage methods on the surface roughness of tissue conditioners. Dent Mater J 2008; 27: 153158.

66) Machado AL, Giampaolo ET, Vergani CE, Souza JF, Jorge JH. Changes in roughness of denture base and reline materials by chemical disinfection or microwave irradiation: surface roughness of denture base and reline materials. J Appl Oral Sci 2011; 19: 521-528.

67) Elsemann RB, Cosme DC, Souto AA, da Silva DF, de Mello JS, Shinkai RS. Degradation of tissue conditioners in complete dentures: an in situ study. Int J Prosthodont 2008; 21: 486488.

68) Gronet PM, Driscoll CF, Hondrum SO. Resiliency of surfacesealed temporary soft denture liners. J Prosthet Dent 1997; 77: 370-374.

69) Maeda T, Hong G, Sadamori S, Hamada T, Akagawa Y. Durability of peel bond of resilient denture liners to acrylic denture base resin. J Prosthodont Res 2012; 56: 136-141. 